\title{
Developing low-carbon economy: Actions, challenges and solutions for energy savings in China
}

\author{
Jian Hou ${ }^{\mathrm{a}, \mathrm{b}}$, Peidong Zhang ${ }^{\mathrm{a}, *}$, Yongsheng Tian ${ }^{\mathrm{a}, \mathrm{b}}$, Xianzheng Yuan ${ }^{\mathrm{a}, \mathrm{b}}$, Yanli Yang ${ }^{\mathrm{a}}$ \\ a Qingdao Institute of Bioenergy and Bioprocess Technology, Chinese Academy of Sciences, Shandong Province, Qingdao 266101, China \\ ${ }^{\mathrm{b}}$ Graduate University of Chinese Academy of Sciences, Beijing 100049, China
}

\section{A R T I C L E I N F O}

\section{Article history:}

Received 9 April 2010

Accepted 26 March 2011

Available online 17 April 2011

\section{Keywords:}

Low carbon economy

Energy savings

China

\begin{abstract}
A B S T R A C T
Global warming and financial crisis have brought severe threats to human existence and economic growth. Utilization of potential for energy savings is necessary for alleviating energy shortage, protecting environment and achieving sustainable economic and social development. This paper has not only comprehensively evaluated the China's energy savings opportunities, but also systematically analyzed the primary challenges and deficiencies in China's energy savings policies, and proposed targeted countermeasures and suggestions. This is of important guiding significance for China to establish a longterm effective mechanism to boost energy-saving technologies and products, and to promote the economic development toward a low-carbon mode.
\end{abstract}

(c) 2011 Elsevier Ltd. All rights reserved.

\section{Introduction}

China, as the fastest developing country, has made remarkable achievements in economic and social development in recent years. With sustained and rapid growth of energy supply and demand, China's primary energy production and total energy consumed reached 2.75 and 3.07 billion tons of standard coal equivalent respectively in 2009 [1]. China is rich in the total energy resources reserves, but possession of energy resources per capita is low, and some deficiencies are seriously restricting the sustainable economic and social development: 1 ) energy resources are difficult to exploit, 2) coal occupies a dominant role in primary energy supply, 3 ) environmental pollution is serious, and 4) the situation of energy supply and demand balance is severe [2]. Implementation of the low-carbon economic strategy, of which the essence is low consumption, low pollution and low emissions, is the key to solve China's energy supply tension and to achieve the economic development environmentally-friendly.

Energy savings means to enhance management for energy use, and to adopt technologically feasible, economically rational and environmentally-and-socially acceptable measures to reduce loss and waste at each stage from energy production to consumption, and to use energy more rationally and efficiently. Since 2008, most developed countries like the USA and EU have adopted low-carbon strategies as approach to step out of global financial crisis [3]. On

\footnotetext{
* Corresponding author. Tel.: +86 532 80662790; fax: +86 53280662778.

E-mail address: eeesc@163.com (Zh.Peidong).
}

the eve of the Copenhagen Climate Conference, China set the target to cut carbon intensity by $40-45 \%$ by 2020 from the 2005 level [4]. Continuing policy of 'paying equal attention to developing and economizing and giving the highest priority to energy savings' is the necessary measure to promote China's economic development toward low-carbon and to ensure the achievement of China's carbon dioxide abatement target.

\section{Current situation of energy savings in China}

\subsection{Laws and standards for energy savings}

The Chinese government attaches great importance to energy savings. Since the policy of reform and opening-up, China has always been placing energy saving strategy as the key measure and the long-term policy to achieve sustainable development. In 1997, the Energy Savings Law of PRC was enacted. Entering the 21st century, China pays close attention to climate change, and actively increases measures for energy savings: 1) making energy saving strategy as an important content in the Medium and Long Term Energy Development Plan(2004-2020), 2) enacting Medium and Long Term Specific Plan for Energy Savings, and 3) specifying 'to cut carbon intensity by 20\%' as a binding index of the economic and social development in the 11th Five-Year Plan for National Economic and Social Development (2006-2010) [5].

In October 2007, Energy Savings Law of PRC was revised and passed in the 30th meeting of the 10th National People's Congress of PRC, which further strengthened the specifications for energy 
savings, added building, transportation and public institutions to prioritized energy savings domains, and requested the central and provincial public financial authorities to arrange special funds for energy savings and to implement favorable pricing and tax policies for energy-saving technical reconstruction. With the passage of the revision of Energy Savings Law of PRC, the National Standards Commission followed-up to have formulated 46 corresponding standards, which include 22 standards for limits on per-unit energy consumption of high energy-consuming products, 5 fuel-economy standards for transportation vehicles, 11 energy-efficiency standards for end-use energy products, and 8 basic energy savings standards for energy metering, energy consumption calculation and economical operation [6]. In October 2010, Suggestions of Formulating the 12th Five-Year Plan for Economic and Social Development was passed in the Fifth Plenary Session of the 17th of the CPC, which again stressed 'accelerating to build a resource-saving and environment-friendly society' [7].

\subsection{Closing down backward production facilities}

Since the release of Notice of Inspecting on Closing Down Small Thermal Power Units and Notice of Quickening Adjustment of Structures of Industries with Excess Production Capacity in 2006, China had shut down small thermal power generators with a total capacity of 34.21 million kilowatts, and had weeded out backward iron manufacture facilities with a total capacity of 60.59 million tons, steel manufacture facilities with a total capacity of 43.47 million tons, and cement manufacture facilities with a total capacity of 140 million tons by the end of 2008 , which in total saved 72 million tons of standard coal equivalent. In the first half of 2009, the government shut down small thermal power generators with a total capacity of 19.89 million kilowatts, which marked the accomplishment of shutting down task in the '11th 5-year' plan ahead of schedule [8]. At the end of 2009, the Ministry of Information and Industry released the First Elimination Catalogue of Backward Energy-consuming Electromechanical Equipment/Products to further promote energy saving technologies in industry. In August 2007, the National Development and Reform Committee, the State Environmental Protection Administration, the State Electricity Regulatory Commission and the State Energy Office jointly released Means for Energy-saving Power Generation Dispatching, which canceled the average distribution of all electricity generators, and specified to reschedule generating capacity among generators according to the principle of giving top priority to energy-saving power technologies. In September 2009, Notice of the State Council Endorsing the Development and Reform Commission and Other Departments' Several Opinions on Restraining Overcapacity and Repeated Construction in Some Industries to Guide the Healthy Industrial Development was issued, which proposed to restrain the excess production capacities and redundant constructions [9].

\subsection{Promoting the use of energy-saving technologies}

In order to accelerate the popularity of latest high-efficiency technologies and equipments, the National Development and Reform Committee announced the first and second Catalogue of National Key Energy-saving Technologies to Promote in May 2008 and December 2009 respectively, and in all 85 high-efficiency technologies were included, which were related to 11 industries involving coal, electricity, steel, nonferrous metal, petroleum and petrochemical, chemical, building, machinery, textile, transportation and construction [10]. The National Development and Reform Committee and other four ministries jointly issued Implementation Program for 1000 Enterprises' Energy savings Actions in April 2006, and by the end of 2008, the evaluated enterprises had in total saved 106.2 million tons of standard coal through energysaving technical innovations [11]. In transportation sectors, the Policy for Automobile Industry Development issued in June 2004 and the Automobile Industry Restructuring and Revitalization Plan issued in March 2009 clearly specified 'leading consumers to buy and use energy-saving, pollution-saving, small-displacement, new-energy and new-power automobiles' [12] and 'strengthening the research and production of energy-efficient and environmentally-friendly Automobiles' [13]. The State Council, the Ministry of Construction and the National Development and Reform Committee had successively released Opinions about Developing Energy-saving and Land-sparing Residence and Public Buildings, Implementation Plan for Building Regulatory System of Energy Savings in State Organ Office Buildings and Large Public Buildings, Ordinance for Energy Savings in Civilian Construction and Ordinance for Public Institution Energy Savings from 2005 to 2008, which specified in detail with energy savings innovations in buildings and public institutions [14]. In October 2009, the National Development and Reform Committee and other five ministries jointly released Opinions on Development of Energy-saving Industry of Semiconductor Lighting, aiming to keep light emitting diode (LED) industry growing at 30\% annually till 2015 [15].

\subsection{The government's key projects in energy savings}

The Medium and Long Term Specific Plan for Energy Savings proposed 10 key energy-saving projects, including upgrading of low-efficiency coal-fired industrial boilers and furnaces, regional combined heat and power plants, utilization of waste heat and pressure, reducing and substituting the use of petroleum, increasing the efficiency in power generation systems, optimizing the overall performance of energy system, energy savings in construction, green lighting, energy savings in government organization, and building monitoring and technology service system. The 11th Five-Year Plan for National Economic and Social Development proposed that the 10 key energy-saving projects would be the key engineering and technological measures for China to achieve the target of cutting carbon intensity by $20 \%$ in " 11 th Five-Year". In July 2006, Guidelines for Implementation of Ten Key Energy-saving Projects was released, which formulated detailed contents to implement for the 10 key energy-saving projects, and planed to save 240 million tons of standard coal equivalent by implementing the 10 key energy-saving projects, which would contribute about $40 \%$ to the achievement of China's energy savings object in the "11th 5-year" period [16]. In 2009, China organized the projects of 'Energy-saving Products Benefiting the Public' and 'Golden Sun Demonstration' to promote energy-saving products and photovoltaic power generation $[17,18]$. Since the implementation of the project of 'Energy-saving Products Benefiting the Public', more than 15 million high-efficiency air conditioners have been popularized, entire efficiency has increased by $15 \%$, about 3.6 billion kilowatthour electricity have been saved and 4 million tons of carbon dioxide emission have been reduced over the past year [19].

\subsection{Fiscal and tax policies for energy savings}

Since 2000, the central budget has arranged over 180 billion Yuan to support energy saving technical reconstruction. This includes industrial restructuring, improving energy utilization efficiency in urban and rural buildings and renewable energy development. In 2008, China launched a 4-trillion Yuan investment plan to address global financial crisis, from which 210 billion Yuan was invested to implementation of energy saving and environmental protection strategies [20]. Provisional Means for Administrating Funds of Financial Incentives to Energy-saving Technical Innovation released in 
December 2007 has proposed to offer financial support to technological reformations included in Guidelines for Implementation of Ten Key Energy-Saving Projects. Provisional Means for Administrating Funds of Financial Subsidies to Promoting High-efficiency Lights released in December 2007, Provisional Means for Administrating Funds of Financial Assistance to Solar Architectural Applications released in March 2009, Provisional Means for Administrating Funds of Financial Assistance to Promoting Energy-saving Products released in May 2009, Provisional Means for Administrating Funds of Financial Assistance to "Golden Sun Demonstration Projects" released in July 2009 and Notification of Providing Financial Compensation to Energysaving Generation Scheduling Test Points released in December 2009 have respectively specified offering subsidies to users purchasing high-efficiency lights, offering subsidies to eligible demonstration projects of application of photovoltaic power generation technologies in different fields such as building integrated photovoltaics (BIVP), offering allowances to enterprises producing high-efficiency products and offering financial compensation to generating sets listed in the annual energy-saving power generation dispatching scheme but ranked poorly and in standby mode [21-26]. China has taken a series of protective price policies to promote renewable energy generation. Notification of Improving Pricing Policies for Wind Power Generation released in July 2009 and Notification of Improving Pricing Policies for Forestry Biomass Power Generation released in July 2010 have respectively specified raising the on-grid price of wind power and biomass power $[27,28]$. China has specified to implement tax breaks for environmentally-friendly and energy-saving projects since 2008, and has unveiled Catalogue of Environmentally-friendly and Energy-saving Projects Enjoying Enterprise Income Tax Privilege [29]. To foster demand for smaller cars with engine size of $1.6 \mathrm{~L}$ or less, the Ministry of Finance and the State Administration of Taxation have regulated to cut the purchase tax in 2009 for this type of vehicles from $20 \%$ to $5 \%$. After economic recovery in 2010 , tax was slightly raised to $7.5 \%$ [30]. China's economic incentive policies for energy savings also concern government procurement of energysaving products. Following the release of Opinions about Government Procurement of Energy-saving Products in 2004, Notification of the General Office of the State Council on the Establishment of compulsory Government Procurement System of Energy-saving Products in 2007 and Notification of Adjustment of the List of Energy-saving Products in Government Procurement in 2009 have further specified the government procurement list and regulation [31,32].

\section{The major challenges and deficiencies facing China's energy savings}

From 2005 to 2009, energy consumption per unit of GDP had been reduced by $15.69 \%$ in China [33]. Energy efficiencies in most industries have made great improvements. However, from the present industrial and energy structures, there are still many obstacles existing in China's energy saving policies and the development of low-carbon economy is confronted with great challenges.

\subsection{Coal still being the main energy resource}

Coal has always been China's main energy resource (Fig. 1), and mass production and consumption of coal is regarded as the major cause for aggravating ecological condition. In 2009, coal production and consumption in China reached 2.58 and 2.56 billion tons respectively, accounting for $45.6 \%$ and $46.9 \%$ of total global coal production and consumption [34]. As China increases in exploiting renewable and new-energy resources, the energy structure has been improved gradually in recent years. However, coal still makes up about $70 \%$ of the energy consumption in power sector in China

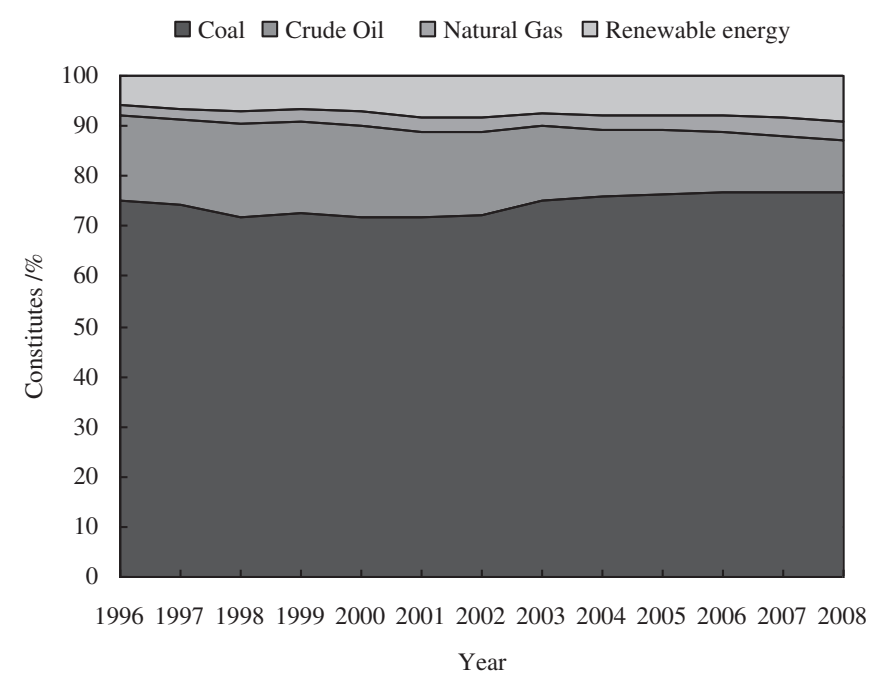

Fig. 1. Constitutes of Energy Production in China [35].

at present. Coal power plant efficiency in China is only about $30 \%$, while in developed countries it reaches above $45 \%$, and emissions from coal-fired power plants constitute over $60 \%$ of the total carbon dioxide emissions in China. To reduce coal mining and improve coal utilization efficiency is the primary issue that must be resolved for China to develop low-carbon economy.

\subsection{Noticeable heavy industrialization}

The development of heavy industry is the main cause for energy consumption in China. In 2007, production value of resourceintensive industries including ferrous metallurgy, nonferrous metallurgy, nonmetal (construction), chemical materials, coal, petroleum, natural gas and electricity made up $71.54 \%$ of the total industrial value added in China and energy consumption of these resource-intensive industries made up $82.88 \%$ of the total industrial energy consumption [35]. The unit product energy consumption is much higher than that in developed countries. Besides, production volumes of heavy industries in China grow rapidly. For example, the percentages of production volumes of steel, cement and chemical fertilizers of China in world market had risen from $8.2 \%, 9.0 \%$ and $17.0 \%$ in 1980 to $31.2 \%, 46.6 \%$ and $43.0 \%$ in 2006 , respectively (Table 1) [36]. To address the global financial crisis in 2008, China has launched the restructuring and rejuvenation programs for ten key industries including steel, automobile, shipbuilding, petrochemical, light, textile, nonferrous metal, equipment manufacturing, electronic information and logistics. Due to China's economic recovery plan, electricity consumption of four major industries including iron and steel, nonferrous metals, building materials and chemicals reached 592.4 billion $\mathrm{kW}$ h in the first quarter of 2010 , which represented $30.53 \%$ increase from the previous year and accounted for more than $30 \%$ of the total electricity consumption [37]. Noticeable trend of heavy industrialization means that China still needs huge amounts of energies to support economic growth.

Table 1

Proportion of China's Heavy-industry Products in the World (\%) [36].

\begin{tabular}{lrlll}
\hline & 1980 & 1995 & 2000 & 2006 \\
\hline Steel & 8.2 & 13.0 & 15.5 & 31.2 \\
Cement & 9.0 & 33.6 & 37.4 & 46.6 \\
Chemical fertilizer & 17.0 & 27.0 & 29.0 & 43.0 \\
\hline
\end{tabular}




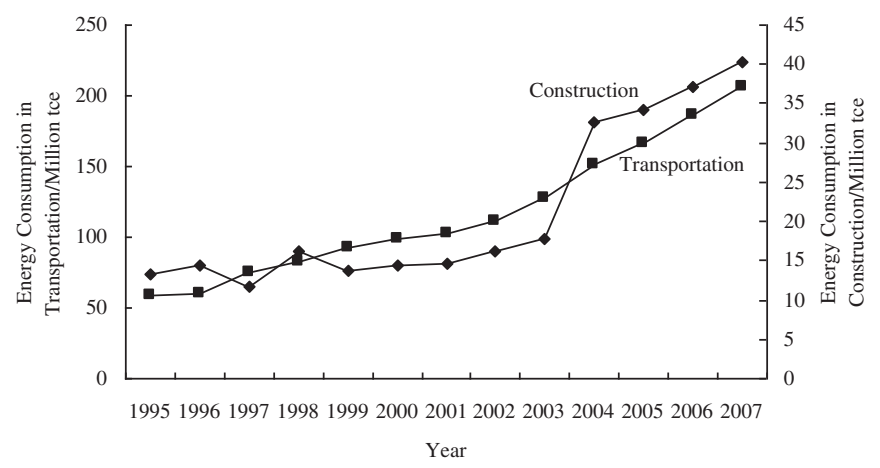

Fig. 2. Trends in Energy Consumption of Transportation and Building Sectors [35].

\subsection{Rapid growth of energy consumption in transportation and building sectors (Fig. 2)}

In 2009, crude oil consumption in China increased by $6.78 \%$ reaching 388 million tons per year, from which 199 million tons was imported. Consequently, China's external dependency on foreign oil reached 51.29\% [38]. The rapid growth of transportation energy consumption is the main cause for the insufficient oil supply. In China, over the last 15 years, number of passenger vehicles on average has increased by $16.74 \%$ annually. There were about 76.19 million passenger vehicles at the end of 2009 and energy consumption in transportation sector accounted for about $20 \%$ of the total energy consumption in China [39]. As China's industrialization going on, the need of traffic and transportation will keep increasing, and the problem of oil shortage will be more prominent (Fig. 3). Based on $10 \%$ annual growth rate, formulated at the early stage of the "11th five-year" plan, the passenger vehicles volume in China will exceed 150 million in 2020 [39]. With the speeding up of urbanization, new buildings and various kinds of household appliances have significantly increased in China, and per-unit area and total energy consumption in construction sector both grow rapidly [40]. Building energy consumption per capita in China is still relative low at present which is about one fifth of that in USA, and with the enhancement of social productivity and people's living standard in China, energy consumption in building sector will further increase [40]. The continuous growth of energy demand in transportation and building sectors results in more difficult tasks for energy savings in China.

\subsection{Insufficient in technological innovation and energy savings management}

For now, most of China's key energy-saving technologies still depend on import from foreign countries, and the high initial

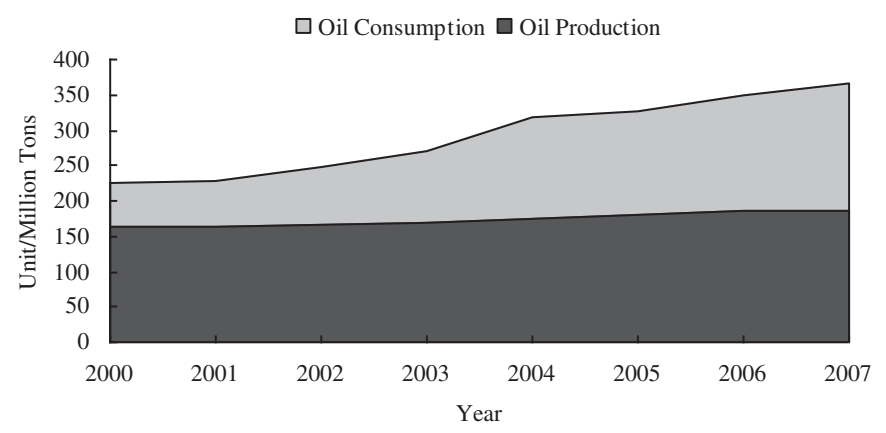

Fig. 3. Petroleum Production and Consumption in China [35]. capital cost of energy-saving technical reconstruction and high price of energy-saving products becomes the main reason why they are difficult to popularize. For example, Integrated Coal Gasification Combined Cycle (IGCC) is difficult to be commercialized in China because of high investment cost and it is estimated that the cost of energy-efficiency house is higher by 100-150 Yuan per square meter than the cost of ordinary house [41]. China adopts the energy efficiency label system in which efficiency labels are marked by producers and importers, and the government implements supervision and management. However, due to the insufficient government administration, there are many firms which mark energy efficiency labels illegally and make use of energy savings allowance to advance the sales of high energy-consuming products, which greatly misleads the consumers and affects the popularity of authentic energy-saving technologies and products.

\subsection{Imperfect pricing mechanism of energy}

China issued Provisional Regulations for Resources Tax in 1993. After years of adjustment, the scope of resource tax has been expanded gradually, but the tax amount is still relatively low. In most provinces the resources tax on coal is less than 4 Yuan/ton [42]. The Finished Oil Tax Reform Program which has been implemented since 1 January 2009 has raised the consumption tax on gasoline from 0.2 Yuan per liter to 1 Yuan, and tax on diesel has been raised from 0.1 Yuan per liter to 0.8 Yuan. But meanwhile, 6 charges including highway maintenance fees, waterway maintenance fees, highway transportation management fees, additional highway passenger and cargo traffic fees, waterway transportation management fees, and additional waterway passenger and cargo traffic fees have been canceled [43]. The overall fuel tax is still at a low level. Moreover, there is no environmental tax in China yet. The price of energy cannot reflect the scarcity of resources, the market supply and demand and the cost of pollution clean-up, thus it is difficult to fundamentally promote the rational use of energy in China.

\section{Suggestions for promoting energy savings in China}

According to the obstacles and deficiencies in China's energy saving policies, in order to establish a permanent and efficient mechanism for energy savings, and to further push economic growth toward a low-carbon mode, the solutions and suggestions below have been proposed.

\subsection{Carry out research on energy savings plan during '12th 5-year' and define development priority and overall arrangement further}

Since the formulation of Medium and long term specific plan for Energy Savings in 2004, as the constant development of energy science and technology, the situation and mission of energy savings China faces have greatly changed. To guarantee the long-term and efficient work of energy savings, it is necessary for China to carry out the research on programming of energy savings in the new era, and to further define the priorities and overall arrangement. It is suggested to organize domestic experts in planning of energy policies and R\&D of energy technologies to comprehensively analyze the trend of global development of energy-saving technologies, and by combining the diversified status of needs of energy-saving technologies, distributions of energy resources and situations of economic development in different areas of China, to determine the priorities and scales of energy-saving projects suitable for different areas so that to further formulate targets, technological roadmaps and policy mechanisms. 
4.2. Increase funding for energy savings and promote innovations of energy-saving technologies

Insufficient R\&D in key technologies is the main problem for energy savings in China. According to that the situation of coal being the main energy resource is difficult to change in the short term and the energy consumptions in transportation and building sectors will keep increasing, it is suggested for China to further increase funding for energy savings, and by relying on scientific institutions and combining the key energy-saving fields and projects, to build teams of innovative R\&D of energy-saving technologies to strengthen own research in technologies of efficient and clean use of coal, technologies of fuel-saving in transportation, new energy-saving products for buildings, technologies of renewable energy generation, biological liquid fuels and designs of renewable energy integrated with architecture. Meanwhile, it is suggested to establish timely industrialization demonstration centers according to the R\&D evolvement of energy-saving technologies. The demonstration effects of the centers will play a positive role in promoting the formation of energy-saving industrial clusters and the popularization of energy-saving technologies.

\subsection{Grab the important opportunities of developing low-carbon economy and advance energy savings in industry constantly}

Energy savings in industry contributed greatly to the achievement of China's energy savings target in the '11th 5-year' period. Industrial energy savings will still be the important effort direction for the achievement of China's carbon dioxide emissions abatement target by 2020. Low-carbon economy brings great challenges for China's industrial development but also brings the opportunity for China to take a new road to industrialization. China must grab hold of this important opportunity to constantly advance energy savings in industry. In the process of re-energizing heavy industries in response to global financial crisis, China must strictly restrict the blind expansion of energy-intensive industries, speed up perfecting the mechanism for closing down laggard facilities, and continue controlling the export of energy-intensive products. Large-scale equipments of energy production and transformation have become the international trend and this is favorable for promoting energy savings and ensuring security of energy production. However, the concentration of energy-intensive industries in China is still low (such as coal, electricity, building, petrochemical and papermaking), and the low technical level of small enterprises is an important course for extravagant energy consumption in heavy industries in China. It is suggested for China to increase the capital concentration and production scale in heavy industries so that to rapidly improve China's overall energy utilization efficiency.

\subsection{Improve fiscal and tax policies for energy savings and establish sound formation mechanism of energy price}

Fiscal and tax policies play an important role of guidance and support to popularize energy-saving technologies and products. At the same time to formulate a series of policies of fiscal subsidies, tax preferences and government procurements in favor of energy savings, China must also speed up the formulation and reformation of other financial and tax policies like resources tax, energy consumption tax and environmental tax so that the role of combined guided effect of various kinds of finance and taxation policies can be played, and a more sensible pricing mechanism for energy can be built. The reforms on resources tax should be intensified: to expand the collection scope and increase tax rate, to impose from production to consumption synchronously, and to change from lump-sum tax to progressive tax. Fuel tax should be further perfected: to conditionally increase levy amount. Environmental taxation system should be defined as soon as possible: to start at low-carbon tax rate that will have small influence on the economic development but can lead to observable carbon dioxide emission reduction.

\subsection{Speed up construction of standard system and strengthen energy-savings supervision}

Establishing scientific and strict index, measurement and verification systems for energy savings is the key to efficiently implement energy savings laws and regulations. Since the promulgation of New Energy Savings Law, China has released a series of standards for energy consumption and efficiency. China must strengthen the researches in the standard systems for energy savings, increase the coverage of energy efficiency standards for products, speed up formulation and amendment of the detailed regulations for the implementation of energy consumption and energy efficiency standards, actively carry on special inspection on "Energy Label" and energy-intensive facilities, firmly prevent illegal energyintensive programs, organize relevant authorities and experts to assess and check on the completion of energy savings plan, and fulfill rewarding and penalty measures.

\section{Conclusion}

Energy savings is a necessary measure for developing lowcarbon economy. Entering the 21st century, China has placed high value on issues of climate change and has taken several measures to promote energy savings, which have gained positive results and have contributed greatly to achieving the energy savings goal in the '11 th 5-year'. For several decades primary source of energy supply in China was coal, and the economic development has overdepended on industrialization. The structures of energy and economy in China are very unbalanced. Under the impact of global financial crisis, the problems of industrial and energy structures become even prominent, and low-carbon economy development faces great challenges. With the improvement of population living standard and continuing rapid development of economy, the energy demand in building and transportation sectors keeps increasing fast, which makes task of achieving high energy savings more difficult. In recent years, China has implemented a series of economic incentive policies to encourage energy savings. But compared with the developed countries, China's investment in energy savings is still low and the energy pricing mechanism is very unreasonable.

To develop low-carbon economy poses severe challenges to China's old mode of economic development which has over depended on energy consumption, but it is also a turning point for China to solve the energy bottleneck, eliminate environmental pollution and improve industrial structure. China must grip this important opportunity of developing low-carbon economy, direct at its major problems and shortcomings, clarify priorities and overall arrangement unceasingly, increase investment, offer full guidance and strengthen supervision, to establish a permanent and effective mechanism for energy savings to push economic growth thoroughly toward a low-carbon mode.

\section{Acknowledgments}

We are grateful with Dr. Yang Xutong and Wu Di for their sincere help. Research of this article has been supported by National Natural Science Funds (40901063) and Special Funding for Public Benefit Research of Environmental Protection Department (2008467087). Thank Chinese Academy of Sciences, National Natural Sciences 
Foundation of China and Ministry of Environmental Protection of the PRC for their assistance.

\section{References}

[1] National Bureau of Statistics of China. China's energy consumption in 2009. Available at, http://www.stats.gov.cn/tjdt/zygg/sjxdtzgg/t20100812_402664 717.htm [accessed 12.08.10].

[2] Ma H, Les O, John G. China's energy situation in the new millennium. Renewable and Sustainable Energy Reviews 2009;13:1781-99.

[3] International Energy Net. Low carbon economy helps tackle financial crisis, climate change. Available at, http://en.in-en.com/article/News/Global/html/ 2009032410905.html [accessed 24.03.09].

[4] Jiang B, Sun Z, Liu M. China's energy development strategy under the low carbon economy. Energy 2010;35:4257-64.

[5] Philip A. China's ongoing energy efficiency drive: origins, progress and prospects. Energy Policy 2009;37:1331-44.

[6] China Energy Netcom Research Center. 46 "Energy-saving Law" supporting national standards are successively implemented since 1 June. Available at, http://www.china5e.com/show.php?contentid=21223 [accessed 10.06.08].

[7] Xinhua News Agency. Authorized to announce: suggestion of formulating 12th five-year plan for economic and social development, http://news. xinhuanet.com/politics/2010-10/27/c_12708501.htm. Available at[accessed 27.10.10].

[8] National Bureau of Statistics of China. China's energy production capacity has enhanced greatly and energy structure is being optimized continually, http:// www.stats.gov.cn/tjfx/ztfx/qzxzgcl60zn/t20090922_402589088.htm. Available at[accessed 22.09.09].

[9] Xinhua News Agency. China to cut more outdated capacity. Available at, http://news.xinhuanet.com/english2010/video/2010-04/07/c_13241322.htm [accessed 07.04.10].

[10] National Development and Reform Commission. Catalogue of national key energy-saving technologies to promote( [2008]No.36 and [2009] No.24). Beijing; 2009.

[11] National Development and Reform Commission. Notice of examination results on energy-saving objectives of 1000 enterprises. Available at, http://www. sdpc.gov.cn/hjbh/hjjsjyxsh/t20091124_315031.htm [accessed 16.10.09].

[12] National Development and Reform Commission. The policy for automobile industry development ([2004] No.8). Beijing; 2004.

[13] State Council. The automobile industry restructuring and revitalization plan (2009-2011). Beijing; 2009.

[14] Zhou N, Mark D. Levine, Lynn P. Overview of current energy-efficiency policies in China. Energy Policy 2010;38:6439-52.

[15] National Development and Reform Commission. Opinions on development of energy-saving industry of semiconductor lighting([2009] No.2441). Beijing; 2009.

[16] National Development and Reform Commission, Ministry of science and technology, the Ministry of Finance, et al. Guidelines for implementation of ten key energy-saving projects ([2006] No.1457). Beijing; 2006.

[17] Ministry of Finance. Notification of carrying on "Energy-saving Products Benefiting the Public Project" ([2009] No.213). Beijing; 2009.

[18] The Ministry of Finance. Notice of implementing "Golden Sun Demonstration Project" ([2009] No.397). Beijing; 2009.

[19] Xinhua News Agency. Expectation effect of energy-saving air conditioner is prominent. Available at, http://news.xinhuanet.com/energy/2010-06/21/c 12244470.htm [accessed 21.06.10].

[20] Xinhua News Agency. Ministry of finance will vigorously support energysaving and emission reduction. Available at, http://news.xinhuanet.com/ energy/2009-08/17/content_11896729.htm [accessed 17.08.09].
[21] Ministry of Finance. Provisional means for administrating funds of financial incentives to energy-saving technology innovation ([2007] No.371). Beijing; 2007.

[22] Ministry of Finance. Provisional means for administrating funds of financia Subsidies to promoting high-efficiency lights ([2007] No.1027). Beijing; 2007.

[23] Ministry of Finance. Notice of ministry of finance publishing provisiona administrating means for funds of financial assistance to solar architectural applications ([2009] No.129). Beijing; 2009.

[24] Ministry of Finance. Provisional means for administrating funds of financial assistance to promoting energy-saving products ([2009] No.213). Beijing; 2009.

[25] Ministry of Finance, State Energy Office. Provisional administrating means for funds of financial assistance to "Golden Sun Demonstration Projects" ([2009] No.397). Beijing; 2009.

[26] National Electricity Regulatory Commission, Development and Reform Committee, State Energy Office. Notification of providing financial compensation to energy-saving generation scheduling test points. Beijing; 2009.

[27] National Development and Reform Commission. Notification of improving pricing policy of wind power generation ([2009] No.1906). Beijing; 2009.

[28] National Development and Reform Commission. Notification of improving pricing policy of forestry biomass power generation ([2010] No.1579). Beijing; 2010.

29] Ministry of Finance. Notification of publishing catalogue of environmentallyfriendly and energy-saving projects enjoying enterprise income tax privilege ([2008] No.115 and [2009] No.166). Beijing; 2009.

[30] Ministry of Finance. Notice of reducing vehicle purchase tax on vehicles with displacement of 1.6 liter and less ([2009] No.12 and [2009] No.154). Beijing; 2009.

[31] State Council. Notification of establishment of compulsory government procurement system of energy-saving products ([2007] No.51). Beijing; 2007.

[32] Ministry of Finance. Notification of adjustment of the list of energy-saving products in government procurement ([2009] No.10). Beijing; 2009.

[33] Xinhua News Agency. China's energy saving and emission reduction actions make good effect. Available at, http://news.xinhuanet.com/environment/ 2009-08/11/content_11862964.htm [accessed 11.08.09].

[34] British Petroleum. BP statistical review of world energy 2010. London; 2010

[35] National Bureau of Statistics. China energy statistics yearbook, http://www. stats.gov.cn/tjsj/ndsj/. Available at[accessed 16.10.10].

[36] Shen L, Liu L. The sustainability evaluation and path selection of China's energy policy. [J].ISTIC PKU CSSCI 2009;1(8):1264-71 [in Chinese].

[37] Xinhua News Agency. Electricity consumption of four major industries remain at high level. Available at, http://news.xinhuanet.com/energy/2010-04/22/c 1248718.htm [accessed 22.04.10].

[38] Xinhua News Agency. China's oil import dependency firstly exceeds warning line. Available at, http://news.xinhuanet.com/fortune/2010-03/29/content 13265670.htm [accessed 29.03.09].

[39] China Energy Netcom Research Center. Energy consumption of transportation sector in China growing continuously, http://www.china5e.com/show.php? contentid=121823. Available at[accessed 19.08.10].

[40] Xinhua News Agency. Energy consumption of building sector in China growing continuously, http://news.xinhuanet.com/house/2010-09/20/c 12590141.htm. Available at[accessed 20.09.10].

[41] China Energy Netcom Research Center. Low-cost energy-saving technologies are waiting in the boudoir to be betrothed, "energy-saving" should not be tags for high-price house. Available at, http://www.china5e.com/show.php? contentid=66788 [accessed 05.01.10].

[42] Xinhua News Agency. China to reform resource taxes. Available at, http:// news.xinhuanet.com/english2010/video/2010-04/07/c_13241319.htm [accessed 07.04.10].

[43] Development and Reform Committee. Finished oil price tax reform program ([2008] No.66). Beijing; 2008. 